\title{
Notes sobre la societat gestionària i de l'assessorament a partir de l'escrutini de dos manifestos
}

\author{
Mauro Valenciano Oller (Universitat de Barcelona)
}

Valdecantos, Antonio. Manifiesto antivitalista. Madrid, Libros

de la Catarata, 2018, 157 pàgs.

Pérez Gordillo, Vanessa. La dictadura del coaching. Manifiesto

por una educación del yo al nosotros. Madrid, Akal, 2019,

257 pàgs.

En l'actualitat vivim una precària realitat social i econòmica que s'ha caracteritzat de diferents maneres, entre elles com societat del risc (Beck, 2013). Aquesta mirada (i també d'altres que podríem aplegar, com ara la de Frank Furedi o de Zygmunt Bauman, totes tres dins de la sociologia contemporània) està propera a la lògica de l'escrutini crític del neoliberalisme. Al costat d'aquesta mirada sociològica, també destaquem la qüestió de la burocratització del món dins del règim neoliberal (Hibou, 2020) com un altre element a tenir en compte per l'estudi de les condicions de vida en el món neoliberal. Ara bé, en aquesta ressenya no es farà servir les ulleres de la sociologia, com podria ser el cas d'haver triat glossar a autors com ara Beck, Furedi o Bauman, que bé mereixen un esment ( $i$, fins i tot, una ressenya en aquesta revista). El punt de partida d'aquest text, però, serà diferent.

Aquest punt de partida ens convida a revisar les concepcions de societat de l'assessorament (Pérez Gordillo, 2019) i de societat gestionària (Valdecantos, 2018), dos conceptes agermanats. Aquesta ressenya pren sengles llibres, i es plantejarà una anàlisi d'aquesta crítica al neoliberalisme des de qüestions pròpiament filosòfiques $i$ ètiques. Recollirem les principals idees presentades per aquests dos autors contemporanis, que comparteixen una base de formació filosòfica, tot i que amb una diferent trajectòria literària.

Aquests dos autors es troben en diferents moments professionals i vitals que es reflecteixen en el gruix de la seva obra publicada. Per una banda, tenim Antonio Valdecantos, nascut l'any 1964, que ha tingut una trajectòria acadèmica i literària abastament reconeguda. Destaquem entre tots els seus treballs -més d'una dotzena de llibres i un nombre encara més gran d'articles i col-laboracions en llibres col-lectius- dos d'ells: La fábrica del bien (Valdecantos, 2008) i El saldo del espíritu (Valdecantos, 2014), a banda del que pròpiament glossarem en aquest text. Per l'altra banda, tenim Vanessa Pérez Gordillo, una autora més jove que Valdecantos i que està just al començament de la seva trajectòria com autora, la qual cosa no treu mèrit a la seva implacable crítica del coaching. Convé mencionar que el llibre de Pérez Gordillo ha servit, tanmateix, com a material de lectura en un seminari dins l'assignatura Economia de l'educació del grup T1 del curs 2020-21 al Grau de Pedagogia de la Universitat de Barcelona, grup del qual soc professor.

Un cop anomenada la diferent circumstància vital d'ambdós autors, direm 
que, a més a més de la seva formació en Filosofia, plantegen una mirada crítica envers la societat que estem construint. A cavall de la qüestió punyent de l'assessorament, entrelligada amb el fenomen coach, tal com ho planteja Pérez Gordillo, i de la dissecció de la idea i pràctiques institucionals de gestió segons Valdecantos (un gruix important de les pàgines del seu llibre Manifiesto antivitalista es consagren a aquest assumpte), trobem la fesomia que pren el neoliberalisme en aquestes darreres dècades. Assessorament, gestió, coaching, neoliberalisme... són els trets demencials del sistema que s'està configurant durant els darrers temps.

Considerem que una cita ens servirà per perfilar la mirada compartida d'ambdós autors: «Llegar a ver que lo acostumbrado es espantoso y mostrar lo que se ha visto. Si tal cosa pudiese lograrse alguna vez, los fines de la filosofía no podrían estar mejor servidos» (Valdecantos, 2018, p. 154). Aquest propòsit que planteja el filòsof madrileny a Manifiesto antivitalista penso que és extensible a la mirada que pren Pérez Gordillo a La dictadura del coaching, i tanmateix procuraré que també sigui la mirada amb la que rellegeixo aquestes lectures. Fer una autòpsia de les nocions d'assessorament i de gestió, ben presents en el pensament contemporani, serà un dels principals propòsits d'aquest text.

Segons Pérez Gordillo, la caracterització del mode de vida contemporani correspon a una societat de l'assessorament. Aquesta idea d'assessorament té un espectre ampli, i es concreta darrerament en el coaching. De fet, l'autora es refereix al coaching com la nova cara de l'assessorament (p. 37). D'entrada, podem anomenar la seva naturalesa mistificadora, que tergiversa la realitat:

Estas tecnologías de los afectos y los talentos, que practican el trabajo en equipo, hacen una repro- gramación mental que consiste en cambiar la enseñanza por domesticación. Todo pasa desapercibido, no sólo porque no nos lo explican, sino porque lo esconden. (p. 82-83)

Paga la pena dir que una de les principals aportacions d'aquesta autora a través del seu llibre és relatar com va caure dins de la boca del llop. Ella explica, amb pels i senyals, com durant anys va creure cegament en les ensenyances del coaching. En el Ilibre rememora com va ser una cadet de l'exèrcit de coachs que, a dia d'avui, s'amunteguen en diferents àmbits. Per tant, podem destacar el caràcter testimonial del llibre, i afegir el fet que ella l'escriu prenent distància del discurs coach.

La introducció del coaching va ser primerament en l'àmbit empresarial. L'assessorament o consultoria forma part de la tradició amb la qual podem relacionar, de manera clara, el coaching. Pérez Gordillo fa una repassada a aquests orígens empresarials del coaching. No obstant, no està de més dir que l'origen del coaching està en la imatge de l'entrenador esportiu (coach en anglès) que dirigeix als esportistes. L'autora anomena aquesta primera referència, aquest primer element previ a l'esclat del coaching a l'àmbit empresarial. Malgrat això és cert, l'autora oblida anomenar una etimologia prèvia al coach esportiu. Durant els segles XVII i XIX, els carruatges que tiraven cavalls eren conduits pels cotxers. Aquests cotxers eren precisament coachs. Per tant, tot i ser ben cert que els coachs esportius són anteriors als coachs empresarials, paga la pena dir que abans hi havia els coachs que conduien els carruatges. Aquests conductors són, per tant, la prehistòria del coaching.

Dit això, el món de l'empresa va ser el primer territori conquerit pel coaching, més enllà de la pròpia dimensió esportiva. Actualment el coaching s'ha estès pertot, i ha teixit un regne de capil-laritats per tots els àmbits de la societat. En el cas concret 
de l'educació, l'autora assenyala que una primera porta d'entrada va ser la formació del professorat. A mesura que el coaching s'estenia per diferents àmbits, la formació dels professors i mestres que tradicionalment estava a càrrec d'altres professors i mestres va acabar en mans dels coachs. No és sempre així, però sí que es cada cop més freqüent. Això no va ser un pas qualsevol: al nostre entendre suposa un buidament continuat dels coneixements que es podien transmetre d'uns docents a uns altres. Si abans importava clarament què s'ensenyava, amb l'arribada dels coachs al camp de la formació de professorat passa a ser inevitable parlar més aviat del com s'ha d'ensenyar. Podem dir que la nova educació (Royo, 2016), o pedagogisme, i el coaching, s'agafen de bracet en aquesta deriva centrada en la metodologia, $\mathrm{i}$ allunyada dels continguts.

En l'actual visió hegemònica de l'educació, centrada en aquesta corrent de la nova educació o pedagogisme, la manera com s'ha d'ensenyar matemàtiques no té a veure amb el que un professor sap de matemàtiques. Si el professor domina les arts sobre les que imaginem té mestratge el coach, podrà ensenyar qualsevol cosa: aquesta és la idea. Els professors, per sortir de la presó de les classes magistrals (gairebé sempre caracteritzades com una transmissió d'informació unidireccional i amb uns alumnes inactius), hauran de posar-se al dia i incorporar les habilitats dels coachs. Aquesta conversió de professor en coach és una de les grans mentides de la visió que s'ha fonamentat en les darreres dècades, i que lamentablement les Facultats d'Educació d'arreu han ajudat a construir. En ocasions, a les aules universitàries es superposen, en les successives classes, els docents que volen perfilar els contorns d'un saber pedagògic basat en la tradició educativa i el pensament, i els docents que s'han casat amb el coaching.
Aquests últims docents, meravellats i encegats pel coaching, no tan sols transmeten un inequívoc discurs coach, sinó que han sucumbit a la idea que ells -o elles mateixes- han d'esdevenir coachs per poder tenir èxit i, sobretot, ser admirats pels seus alumnes. No ajuda el fet que ara les institucions d'ensenyament superior avaluïn el professorat en base a les enquestes de satisfacció dels alumnes. I ja sabem que si una assignatura és més ardu treure una bona nota, i fins i tot es fa difícil aprovar pels més mandrosos i poc estudiosos, l'avaluació d'una part de l'alumnat pot ser severa, per no dir una rebequeria en tota regla. Un docent coach plantejarà una avaluació de l'assignatura sense examen, sense lectura de llibres (potser algun article, i para de comptar), amb nombrosos treballs en grup.

Seguint aquest fil, la seducció és un dels elements propis del coaching. I és per això que si un docent es veu a si mateix com «un mag sense màgia» (parafrasejant el títol del cèlebre llibre de Mara Selvini), no tindrà gaire motius de pes per resistirse a afegir-se a les files del coaching. Com tampoc molts altres docents es resistiran gaire a abraçar l'església laica del valors, dels projectes, de la inclusió. O fins i tot la teoria de les Intel-ligències Múltiples de Howard Gardner, que la pròpia Vanessa Pérez Gordillo es dedica a criticar, tot situant aquest plantejament a la mateixa alçada moral que el coaching. Per tant, a nivells mínims. L'autora ens adverteix que la porta d'entrada del coaching en el món de l'educació va ser la formació de professors i mestres. Tanmateix, ara els coachs també es dediquen a formar directament als alumnes: per exemple, preparant-los per respondre millor a les proves PISA (p. 164).

Una reflexió que paga la pena fer, i que va una mica més enllà de la pròpia tasca de ressenyar un (o més) llibre(s), té a veure amb la següent qüestió. Tradicionalment, 
la Pedagogia va estar influïda sobretot per la Filosofia. A partir d'un cert moment (posem les acaballes del segle XIX i les dues primeres dècades del segle XX), la Pedagogia es va agermanar amb la Psicologia. Bé, més aviat podem dir que la Pedagogia es va "psicologitzar". Per tant, de la influència inicial de la Filosofia es va passar a una segona línia d'influència: la Psicologia. Seguint amb aquest raonament, podem dir que a hores d'ara estem vivint en un tercer moment, o etapa, en les influències que ha rebut la Pedagogia. Podem dir que el coaching li ha arrabassat aquest rol d'influència primordial sobre la Pedagogia a la Psicologia, i que per tant estem davant d'una nova filiació. Els raonaments que puguem fer d'aquesta transformació progressiva escapa a l'abast d'aquesta ressenya, tot i que no volíem deixar d'anomenar aquesta qüestió i deixar-la, tanmateix, apuntada.

La influència més òbvia del coaching empresarial ha estat el coaching esportiu, ja ho hem indicat. Ara bé, hem d'aclarir que els entrenadors esportius no necessàriament actuen com els coachs empresarials, o com els coachs de vida (life coach). Aquest últim és un coach que esdevé gairebé un terapeuta, però sense la formació i acreditació necessària. Hem d'aprofitar aquest aclariment per reivindicar la figura de l'entrenador esportiu que no segueix el manual del coaching sorgit en els àmbits empresarials, i que després ha arribat arreu. El coach empresarial és un coach esportiu desfigurat, passat pel filtre del neoliberalisme.

L'educació és una de les parades en aquest camí d'expansió per tots els àmbits de la societat. Així és com arribem a un dels altres trets característics del coaching: I'intrusisme. El coach nutricional substitueix el paper que podria fer el metge de família o, més recentment, un diplomat o graduat universitari en Nutrició Humana i Dietètica. El coach educatiu li pren el Iloc al professor, o al formador de professors. Els coachs empresarials en ocasions li fa la feina bruta als departaments de Recursos Humans de les empreses: quan es dissenya un acomiadament massiu, es contracta personal extern -una legió de coachs- per vendre-li la moto als treballadors que acabaran acomiadats. El missatge és que estan acomiadats, els pagaran quadre duros d'indemnització per any treballat, i que aquesta situació és una oportunitat. Gairebé un regal. La persona podrà evolucionar un cop expulsada de l'empresa. Finalment, el coach de vida ocupa el lloc del terapeuta, sense que hagi fet ni una especialitat en Psiquiatria a Medicina, o una formació en el Grau de Psicologia, o en el de Teràpia Ocupacional. Per tant, en tots els àmbits de la societat apareix aquesta dimensió de l'intrusisme, que configura un dels altres elements propis del coaching.

Hem indicat que la seducció era una de les característiques pròpies del registre propi del coaching. El coach és seductor/a de manera oberta i escandalosa amb el seu aprenent, que rep el nom de coachee. Aquesta aproximació seductora resulta poc clara, però aconsegueix el seu objectiu: captar l'interès de persones en situació de fragilitat. L'empresari que vol reflotar l'empresa familiar que ha deixat caure voldrà creure's tot l'edifici del coaching. El coach de torn tindrà via lliure per dir-li que pot reflotar l'empresa, i que aquesta crisi empresarial és una oportunitat pel creixement personal. En aquestes circumstàncies els coachs col-loquen el seu producte i el fan circular. Els consultors - una subespècie dels coachs- treballen com fan els advocats: a partir del que s'anomenen hores facturables.

Pérez Gordillo té molta traça a l'hora de descriure com ella va poder escapar del mercadeig del creixement personal. Va estar atrapada en aquest món del coaching, i 
se'n va sortir prou bé, a jutjar per les seves reflexions al llibre. Va aconseguir escapar d'aquest món ple de promeses per canviar un mateix a partir de determinats trucs de firaire, d'aquest món farcit de frases motivacionals que semblen sofisticades però són obvietats, i va poder plantejar una visió crítica d'allò que en el seu moment va guiar la seva praxi professional (i entenem que també personal).

Hem vist les arrels esportives i empresarials dels coaching abans de desembarcar en l'àmbit educatiu. Però aquesta no és I'única influència destacable. També tenim la psicologia positiva, una tradició de pensament que va desenvolupar-se durant la primera meitat del segle $X X$ als EUA. Aquesta tradició és un element indestriable del que ha estat el feix d'idees que han conformat el coaching, i per tant és una de les referències que necessàriament hem de tenir en compte. Pérez Gordillo anomena aquesta filiació en el seu llibre. Per complementar aquesta mirada, resulta molt oportú anomenar el treball de Barbara Ehrenreich, que la pròpia Pérez Gordillo cita en el seu llibre (per exemple, p. 61). Parlem de l'excel-lent Ilibre Sonríe o muere (Ehrenreich, 2018).

La seducció com element catalitzador de la metodologia coach; la influència de l'àmbit esportiu, l'empresarial i de la psicologia positiva; la progressiva expansió del coaching a diferents àmbits de la societat, amb el fenomen de l'intrusisme vinculat a tot això. Aquests són alguns dels elements sobre els quals Pérez Gordillo posa l'accent en el seu brillant treball de debut. Ara bé, una de les crítiques que volem fer del seu llibre és la qüestió de la no distinció entre teràpies i coaching. L'autora posa dins del mateix sac el coaching i les teràpies. Encara que en ocasions hi ha teràpies que recorden a la manera de fer seductora i confusa del coaching, en altres casos les teràpies (com en determinats contextos la clínica psicoanalítica, encara que no podem dir sempre) tenen un bagatge molt més profund i ric que no el coaching. En determinat tipus de teràpies batega un esperit diferent al coaching, i això és un aspecte que l'autora passa per alt. Ara bé, aquest posicionament esbiaixat de Pérez Gordillo respecte les teràpies no impugna, ni de bon tros, la resta dels seus raonaments, encara que planteja que en el seu discurs existeix una confusió entre les possibilitats de canvi personal que es pot plantejar en determinat tipus d'entorns terapèutics, i la farsa de canvi pròpia del gruix de les propostes de coaching. No tot en teràpia és farsa, com passa certament -estem de tot d'acord amb ella- en el gruix del coaching.

Resulta oportú dir, enllestint aquesta primera part de la ressenya que hem dedicat a La dictadura del coaching, que un dels altres elements inexcusables sobre els quals gira la crítica del coaching és evidenciar el seu caràcter inequívocament antiil.lustrat. A mesura que llegim les pàgines del llibre, ens trobem amb la seva imponent i lapidària crítica del coaching, descobrint que el rei esta nu. El coaching és un aparent humanisme (Abraham Maslow és sovint citat en els cercles del coaching) però a fi de comptes un discurs anti-il.lustrat, una riuada de paraules boniques que estan buides. Un exemple d'aquest èmfasi de crítica i revisió el trobem en el següent fragment:

\footnotetext{
Invito a que nos cuestionemos si las enseñanzas del pensamiento positivo concretadas en el coaching -nueva cara del asesoramiento- son compatibles con la tarea emancipadora de la Humanidad y la construcción de la vida digna -vieja cara de las humanidades. (p. 37)
}

Per tant, quan parlem del llibre de Pérez Gordillo estem davant d'un nou exercici de revisió crítica del desmantellament de les humanitats, com darrerament hem vist altres bonics -encara que terrorífics en 
la seva diagnosi- exemples (Llovet, 2011; Luri, 2012; Royo, 2016).

Un últim apunt sobre el llibre de Pérez Gordillo, abans d'entrar a tractar les principals idees de l'altre llibre que glosarem. Pensem que és important indicar la connexió que existeix entre els propòsits dels neoliberalisme i l'estratègia econòmica i social que es perpetua amb el coaching. El coaching és una eina més, una de les més potents, a l'abast dels interessos del neoliberalisme. Podem dir que hi ha un règim d'ocultació dels problemes i dificultats estructurals del sistema capitalista en la visió del coaching: ens trobem que el lema «si vols, pots» és la condemna per qualsevol lectura crítica del món en clau de lluita de classes. La classe obrera oprimida es manté cega davant de l'explotació dels capitalistes mentre s'apuntin solucions terapèutiques o pseudo-terapèutiques, enlloc d'enfrontar la qüestió de les desigualtats i de la pobresa. Serveixi el següent fragment per il.lustrar aquest apunt:

Los ojos del mundo hiperindividualizado se habitúan a la morbosidad sin percibir el sufrimiento que habita en ella. Despolitizados, buscan las soluciones a sus problemas en una cultura terapéutica que germinó tiempo atrás. (p. 63)

Un cop fet aquest passeig per La dictadura del coaching, anem a destacar els continguts més llustrosos de l'obra d'Antonio Valdecantos que porta per títol Manifiesto antivitalista. Es tracta, com de l'altre llibre que hem ressenyat, d'un text que segueix la forma de manifest. Segurament un dels manifestos més famosos de la història és el text de Marx i Engels del Manifest comunista (1848). No resulta gens estrany que en els temps actuals hi hagi assaigs arrelats en aquest tipus de gènere. L'avançament en les relacions capitalistes a l'ombra del neoliberalisme reclama aquests posicionaments vehements, i per tant resulta pertinent escriure -i pensem que també ho és glossar aquests tipus de llibres- textos que funcionin com armes llancívoles contra el sistema neoliberal.

Una de les primeres qüestions a les que Valdecantos li pren la mida és la noció o concepte d'aprofitament. Segons ell, vivim una època en la qual resulta un assumpte cabdal que s'aconsegueixi l'aprofitament del propi jo. En una línia agermanada amb la crítica del coaching que fa Pérez Gordillo, Valdecantos ens adverteix que quan es desferma aquest aprofitament incansable, estem davant d'una situació de mal pronòstic. Al costat de l'anàlisi d'aquesta noció d'aprofitament, que enllaça amb l'evolució del marc de l'administració al marc de la gestió, Valdecantos també aborda nocions claus en la seva obra, com és la distinció entre emocions i passions (p. 84), que és una crítica oberta a l'educació emocional i la Intel-ligència Emocional, així como la crítica a la retòrica dels valors (p. 153). Això també plantejaria lligams temàtics amb la crítica de Pérez Gordillo a la Teoria de les Intel-ligències Múltiples.

No obstant, tornem a la qüestió dels valors. Els valors es diferencien del que coneixem com virtuts, encara que aquesta especificitat no apareix en aquest text que ressenyem, si bé sí que ho fa dins un briIlant tercer capítol del seu llibre El saldo del espíritu (Valdecantos, 2014, p. 97-140). Aquests dos eixos (emocions - passions i valors - virtuts) funcionen com dos posicionaments clau en la trajectòria del filòsof madrileny, que és un antagonista de les concepcions ensucrades de l'educació contemporània. L'autor ens posa sota avís de la malastrugança educativa que pot arribar a suposar confiar l'educació de les noves generacions en els valors i les emocions, centrant-se ell sobretot en l'àmbit universitari. Resulta especialment elegant i irònic un article que l'autor va publicar uns anys enrere, i que retrata les misèries 
de l'acadèmia (Valdecantos, 2009). Al nostre entendre, aquesta sospita relativa als valors i les emocions s'hauria d'estendre també -per aconseguir un plantejament més saludable en l'educació- envers el treball per projectes, així com també el culte a la innovació i a les competències.

La idea de competició és una altra que l'autor revisa i analitza amb rigor (p. 118). Per un costat, en la modernitat ha esdevingut una desactivació dels combats agonals. Per un altra costat, també en la modernitat s'inaugura un nou tipus de certamen: el combat amb un mateix. Aquest segon aspecte és el que Valdecantos emfatitza més, i que certament ens lliga amb el projecte de millora d'un mateix que funciona al voltant del coaching. Aprofitament al màxim de tots els recursos a l'abast, així com una lluita interior dins de cadascú dels fidels del coaching, són dues de les característiques de la construcció de la subjectivitat de l'emprenedor. De manera coherent amb l'esborrament dels elements estructurals de la realitat econòmica quan es segueix el lema «si vols, pots» del coaching, l'apologia de l'emprenedor encaixa perfectament amb aquest esborrament, i amb la consideració que la millor manera de treballar és «ser empresari de si mateix». En aquesta revisió de la condició agonal del nostre temps, Valdecantos ho expressa en termes de la translació del camp de batalla: d'un camp extern -com era tradicionalment- al camp intern, psicològic. Per tant, el trasllat de l'àmbit exterior i públic a l'àmbit interior, privat, íntim.

En aquest sentit és important relligarho amb el concepte de repte, ben present en la retòrica del coaching. Valdecantos recull explícitament aquest concepte de repte com a sinònim de competició (p. 53), tot i que no fa una anàlisi detallada del concepte de repte en el seu llibre. Un repte és un duel, i un duel es planteja -així ho era fins fa no gaire- envers algú altre. La casuística pròpia de la modernitat, seguint les reflexions de Valdecantos, apunta però a una lluita interna, amb un mateix. Com bé sabem, el resultat d'una contesa és binària: victòria o bé derrota (i en alguns casos excepcionals, es contempla la possibilitat d'empat). En el cas de la lluita amb un mateix, dels reptes que en el coaching figuren com elements per l'auto-construcció personal, hem de tenir present que la pròpia persona es sentirà guanyadora i perdedora. En algun sentit haurà superat el repte, però també haurà de sentir-se perdedora. El producte del repte és sempre per la via de la victòria i de la derrota també, bé s'apliqui a la lluita agonal clàssica, bé s'apliqui als dispositius propis de la subjectivitat neoliberal que ordenen el nostre temps.

Segons es construeix en el camp del coaching, les persones han d'enfrontar reptes per poder superar-los. Els reptes serien l'equivalent modern a les aventures. Ara bé, aquests reptes minen la pròpia persona perquè originalment el repte és una categoria en la qual l'enfrontament es plantejava amb algú altre, no amb un mateix. Al traslladar el repte a la dimensió personal, íntima, el que es planteja és que la persona surti simultàniament victoriosa i derrotada. Aquesta transformació de la idea de competició porta a què les persones visquin la seva evolució íntima com una mena de guerra civil.

Fets aquests apunts sobre el concepte d'aprofitament i també sobre el de competició, anem a abordar ara una altra qüestió: la idea de gestió i, lligada a la gestió, la innovació. Totes dues concepcions tenen un arrelament fort en pedagogia contemporània. La qüestió de què és el que configura l'anomenada societat gestionària resulta clara per l'autor, encara que ho presenta fent una circumval.lació trepitjant la dimensió política: 
Ocurre, pues, que la política tradicional quería cosas que no podía lograr y renunciaba a logros que sí estaban en su mano, mientras que la moderna no puede renunciar a nada que esté a su alcance (en esto es estrictamente tiránica) y no puede proponerse nada que la exceda (en esto es estrictamente económica o administrativa). La esencia de la política moderna es su conversión en una tiranía administrativa o en una administración tiránica. A aquello sobre lo que manda cabe llamarlo la sociedad gestionaria. (p. 109)

Tal com apunta Valdecantos, la política moderna es distingeix de la política tradicional en que la moderna incorpora tota la dimensió pròpia de la gestió. L'èmfasi en l'administració tirànica de la política moderna no és gens desmesurada, sinó que apunta a la realitat d'una política sense política, com ens fa notar Alain Badiou, o fins i tot com un demos sense demos, tal com apunta José Benegas.

La gestió, segons Valdecantos, esdevé de fet «gestió d'un projecte» (p. 146). Un projecte que no té com a objectiu arribar a completar-lo, sinó més aviat anar avançant sense arribar al final. Segons l'autor, un cop queden alguns elements del projecte per assolir-se, aquests elements s'aprofiten per dissenyar un nou projecte. Per tant, el projecte de gestió, o la gestió d'un projecte, no té com a finalitat completar-lo sinó fer-lo servir per crear nous projectes. La gestió és aquest art d'anar encadenant projectes, sense un clar assoliment d'objectius. No podem oblidar que són els projectes els que aconsegueixen subvencions de la Unió Europea, i que la finalitat de presentar determinat projecte no és aconseguir determinat propòsit 0 objectiu mentre es desenvolupa el projecte, sinó rebre novament alguna font de finançament.

Fins fa no fa gaire temps, fer bé les coses volia dir fer-les de manera virtuosa. És a dir, realitzar una tasca i complir determinats objectius, amb un nivell alt d'excel.lència. Hi havia un contingut de la tasca i aquest s'havia de fer amb seny i seguint un criteri. Ara, no obstant, la tasca consisteix en propulsar nous projectes, i en això es basa precisament la gestió:

\begin{abstract}
El éxito de la gestión no consiste en disfrutar de la gloria del cumplimiento, sino en convertir aquello que falte por completar el proyecto en parte de otro proyecto posterior, en una parte renovada que no sea vista como la pesada herencia de tiempo anteriores, sino como algo concebido de nueva planta. (p. 147)
\end{abstract}

Aquest és un raonament clau per entendre els nostres temps, i del que trobem algunes mostres notòries en d'altres fonts. Potser una de les més eloqüents que podríem incloure en aquest treball és la següent:

Desde preescolar hasta posgrado, los centros de formación han llegado al consenso de que la educación tiene que trabajar por proyectos. Los alumnos ya no deben tener como horizonte final el examen o la conclusión de una asignatura, sino la presentación de la memoria de un proyecto. Se trata de una de las palabras clave de nuestra época. La pedagogía de la proyección te prepara para un futuro laboral en que gran parte del tiempo lo dedicarás a la generación incesante de nuevos proyectos. (Carrión, 2020, p. 61)

Vist tot això, on queda la dimensió pròpia del treball?

\begin{abstract}
El trabajo era una actividad permanente que hacía a la identidad del sujeto. El éxito, en cambio, es exterior y no implica esfuerzo, ni dedicación, ni un "saber-hacer". Se puede tener éxito por un golpe de suerte, por una transacción dudosa, por un meritorio recorrido. No importa cómo se logre ni qué medios se utilicen para conseguirlo. No hay más ética que la de los fines. El éxito es el "secreto", la "magia" de la que Carnegie hablaba, y no se alcanza merced al trabajo. (Papalini, 2015, p. 249)
\end{abstract}

Per tant, podem dir que el treball té com antagonistes els projectes i la gestió. Hem passat de l'estabilitat d'una identitat fonamentada en la consciència de classe o en un ofici, a la tremolor d'una identitat accelerada a cop de projecte.

Un breu esment, després d'aquestes reflexions, a la idea d'innovació. Segons Valdecantos, la innovació forma part de la gestió, doncs fonamentalment gestionar 
és anar afegint innovacions. Aquestes innovacions no tenen que ser necessàriament més eficaces que les anteriors mesures emprades. Ara bé, la lògica expansiva i invasora de la gestió necessita d'un creixent volum d'innovacions. L'objectiu de disposar un ventall d'innovacions no és la millora continuada entesa de la manera virtuosa, com de vegades es vol suggerir, sinó mantenir girant la roda de la gestió. Innovar és necessari, inevitable no en la mesura que es volen aconseguir millores, sinó en la mesura que la gestió requereix que no fem el mateix d'ahir, sinó alguna cosa diferent. I diferent, o nou, no vol dir millor, sinó simplement com quelcom diferent al que fèiem ahir.

Hem vist com en la nostra època es passa d'una visió tradicional de la política a una visió moderna, en què es fa un salt de la dimensió econòmica i administrativa a la dimensió de la gestió. Tanmateix, no podem deixar d'esmentar que la gestió és en ocasions oportunament vinculada al management, i que el management té estrets lligams amb l'assessorament i el coaching. Com ja havíem vist que passava, de fet, entre la consultoria i el coaching.

Finalment, volem enfocar el final d'aquest treball subratllant que tots aquests elements que hem vist confeccionen una xarxa de significats i motius compartits. Entre el llibre de Pérez Gordillo i el de Valdecantos hi ha un diàleg possible, a partir de categories veïnes que hem volgut agermanar. Ara, per fer el tancament d'aquesta ressenya, farem esment a algunes qüestions que travessen els discursos d'ambdós textos. En tots dos llibres podem trobar les idees:

1) En el món actual triomfa una tendència anti-il/lustrada. Aquests dos autors subratllen l'assumpte que el gir de les societats contemporànies (sigui sota la de- nominació de societat de la gestió, o gestionària, segons Valdecantos, o societat de I'assessorament, segons Pérez Gordillo) ens duu irremeiablement cap un món allunyat de l'esperit il.lustrat. La tendència a conformar una tradició buidada de continguts i allunyada del món de les virtuts pavimenten els projectes empresarials, farcits de gestió i coachs, així com també omplen de mines tot l'ampli espectre de l'ensenyament. La universitat és una d'aquestes institucions sistemàticament buidades de continguts (Valdecantos, 2009; Llovet, 2011).

2) Hem passat d'una dimensió colllectiva a una individual, oblidant el paper clau de la comunitat. En el cas de Valdecantos, ho veiem en la seva radiografia sobre la competició. El repte, o competició, abans era una situació agonal col-lectiva, i ara és una lluita amb un mateix. En el cas de Pérez Gordillo, la seva crítica al coaching es fonamenta en la deriva cap a l'excessiva individualització, el consumisme i el culte narcisista d'un mateix. Ella planteja com a solució prendre algunes de les idees pròpies de les comunitats indígenes a Amèrica Llatina. El que trobem en els dos llibres és la denúncia envers el descuit de les dimensions comunitàries. Una solució més reeixida i consistent que la que proposa Pérez Gordillo en els seus plantejaments seria la de Jodi Dean a Necessitem camarades (Dean, 2020), que revisa els pressupòsits del comunisme, i que resulta una lectura excel.lent.

3) Ambdós textos poden ser llegits com un arxiu de fitxes policials dels enemics de la causa humanista i il/lustrada. Un altre aspecte rellevant de tots dos llibres és que s'identifiquen obertament, sense embuts, les formes criminals amb les quals s'està canviant el món i s'està duent-lo cada cop més cap a satisfer els interessos neoliberals. Tenim les categories d'aprofitament; les de gestió i d'innovació; també la nova 
visió del repte o la competició (amb un mateix), que ha tractat meticulosament Valdecantos (2018). També tenim les categories de coach i de coaching; el fenomen de l'intrusisme professional; la seducció del coach, que tot plegat aborda amb lucidesa Pérez Gordillo (2019). Quan posem aquestes categories unes al costat de les altres, podem composar-nos un quadre més clar de l'horror que s'està conformant. I les podem prendre com les fitxes policials que es poden servir per evitar que ens aixequin la camisa.

Ras i curt, estem davant d'una realitat monstruosa que passa massa sovint per modèlica, per idíl.lica. Arribats a aquest punt, convé recuperar una primera reflexió que va esperonar la visió que volíem plasmar en aquesta ressenya:

Llegar a ver que lo acostumbrado es espantoso y mostrar lo que se ha visto. Si tal cosa pudiese lograrse alguna vez, los fines de la filosofía no podrían estar mejor servidos. (Valdecantos, 2018, p. 154)

Aquesta reflexió d'adonar-nos de la magnitud de la tragèdia és sense cap mena de dubtes necessària, i suposa el pas anterior indispensable per poder donar un tomb a aquesta situació. Si bé és cert que actualment el pensament es troba terriblement afeblit, i que triomfen les tendències anti-il.lustrades, tot això es fonamenta en el domini ideològic a la que ens sotmetem voluntàriament en la mesura que ens escoltem de bon grat les cantarelles de l'assessorament, el coaching i la gestió.

\section{Referències}

Beck, U. (2013) La sociedad del riesgo. Hacia una nueva modernidad. Barcelona, Paidós.

Carrión, J. (2020) Lo viral. Barcelona, Galaxia Gutenberg.

Dean, J. (2020) Necessitem camarades. Entusiasme, alegria, disciplina i coratge. Manresa, Tigre de Paper.

Ehrenreich, B. (2018) Sonríe o muere. La trampa del pensamiento positivo. Madrid, Turner Publicaciones.

Hibou, B. (2020) La burocratización del mundo en la era neoliberal. Madrid, Ediciones Dado.

Llovet, J. (2011) Adéu a la Universitat. L'eclipsi de les humanitats. Barcelona, Galaxia Gutemberg.

Luri, G. (2012) Per una educació republicana. Escola i valors. Barcelona, Editorial Barcino.

Papalini, V. (2015) Garantías de felicidad. Estudio sobre los libros de autoayuda. Buenos Aires, Adriana Hidalgo editora.

Royo, A. (2016) Contra la nueva educación. Por una enseñanza basada en los conocimientos. Barcelona, Editorial Plataforma.

Valdecantos, A. (2008) La fábrica del bien. Ensayo sobre la invención de la moral. Madrid, Editorial Síntesis.

Valdecantos, A. (2009) «Reforma universitaria y libertad intelectual». Avances en supervisión educativa, núm. 10. Disponible a: https://avances.adide.org/index.php/ ase/article/view/400/258 [Data accés: 22.7.2021].

Valdecantos, A. (2014) El saldo del espíritu. Barcelona, Herder. 